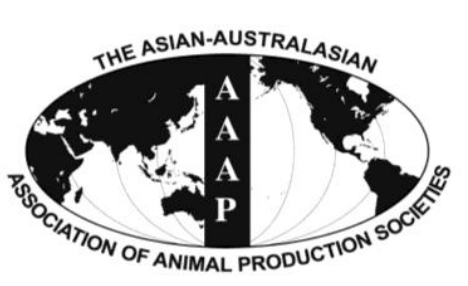

Open Access

Asian Australas. J. Anim. Sci.

Vol. 27, No. 9 : 1319-1327 September 2014

http://dx.doi.org/10.5713/ajas.2014.14193

www.ajas.info

pISSN 1011 1-2367 elSSN 1976-5517

\title{
The Optimum Feeding Frequency in Growing Korean Rockfish (Sebastes schlegeli) Rearing at the Temperature of $15^{\circ} \mathrm{C}$ and $19^{\circ} \mathrm{C}$
}

\author{
Rahman Md Mizanur ${ }^{1,2}$ and Sungchul C Bai ${ }^{1, *}$ \\ ${ }^{1}$ Department of Marine Bio-Materials and Aquaculture/Feeds and Foods Nutrition Research Center, \\ Pukyong National University, Busan 608-737, Korea
}

\begin{abstract}
Two feeding trials were conducted to determine the optimum feeding frequency in growing Korean rockfish, (Sebastes schlegeli) reared at the temperatures of $15^{\circ} \mathrm{C}$ and $19^{\circ} \mathrm{C}$. Fish averaging $92.2 \pm 0.7 \mathrm{~g}$ (mean \pm standard deviation $[\mathrm{SD}]$ ) at $15.0 \pm 0.5^{\circ} \mathrm{C}$ and $100.2 \pm 0.4 \mathrm{~g}($ mean $\pm \mathrm{SD})$ at $19.0 \pm 0.5^{\circ} \mathrm{C}$ water temperature were randomly distributed into each of 15 indoor tanks containing 250 - $\mathrm{L}$ sea water from a semi-recirculation system. A total of five feeding frequency groups were set up in three replicates as follows: one meal in a day at 08:00 hour, two meals a day at 08:00 and 17:00 hours, three meals a day at 08:00, 14:00, and 20:00 hours, four meals a day at 08:00, 12:00, 16:00, and 20:00 hours, and one meal every 2 days at 08:00 hour. Fish were fed at the rate of 1.2\% body weight (BW)/d at $15^{\circ} \mathrm{C}$ and $1.5 \% \mathrm{BW} / \mathrm{d}$ at $19^{\circ} \mathrm{C}$. At the end of $8 \mathrm{wks}$ of feeding trial weight gain and specific growth rate were significantly higher at the fish fed groups of one meal a day and two meals a day at $15^{\circ} \mathrm{C}$ and fish fed groups of 1 meal every 2 days at $19^{\circ} \mathrm{C}$ were significantly lower than those of all other fish fed groups. Glutamic oxaloacetic transaminase and glutamic pyruvic transaminase of fish fed group at 1 meal every 2 days was significantly higher than those of all other fish fed groups in both experiments. Weight gain, specific growth rate and condition factor were gradually decreased as the feeding frequency increased. The results indicate that growing Korean rockfish 92 and $100 \mathrm{~g}$ perform better at $15^{\circ} \mathrm{C}$ than $19^{\circ} \mathrm{C}$ water temperature. As we expected, current results have indicated that a feeding frequency of 1 meal a day is optimal for the improvement of weight gain in growing Korean rockfish grown from $92 \mathrm{~g}$ to $133 \mathrm{~g}$ at $15^{\circ} \mathrm{C}$ and $100 \mathrm{~g}$ to $132 \mathrm{~g}$ at $19^{\circ} \mathrm{C}$ water temperature. (Key Words: Growing Korean Rockfish, Sebastes schlegeli, Feeding Frequency, Water Temperature, Growth Performance)
\end{abstract}

\section{INTRODUCTION}

Korean rockfish (Sebastes schlegeli) is one of the most commercially important and second largest marine finfish species in Korea (Bai and Okorie, 2009). It has several important characteristics for aquaculture such as good tolerance to low water temperature, growth, survival and easiness of seedling production due to the viviparous reproduction style (Lee et al., 2000; Moore et al., 2000).

\footnotetext{
* Corresponding Author: Sungchul C. Bai. Tel: +82-51-629-7922, Fax: +82-51-628-687, E-mail: scbai@pknu.ac.kr

${ }^{2}$ Member of Bangladesh Civil Service (Economic) Cadre, Planning Commission, Ministry of Planning, Dhaka 1207, Bangladesh.

Submitted Mar. 13, 2014; Revised May 8, 2014; Accepted May 27, 2014
}

Within a given species, numerous factors can influence fish growth, among which the most important are probably temperature and feeding (Gardeur et al., 2007). Temperature regulates metabolic activity and all fish species are characterized by a range of temperature within which growth is maximal (Person-Le Ruyet et al., 2006; Bjornsson et al., 2007). The optimum water temperature increases metabolic rates and also increased feed demand of fish. On the other hand, low temperature causes sluggishness by retarding the digestion speeding of fish (Park et al., 2012). Feeding frequency is an important factor to establish an appropriate feeding management program. And for proper aquaculture management, the feeding time and amount have to be set appropriately. Fish growth is influenced by a number of factors, such as feeding frequency, feed intake, 
feed type and feed ration. Hutson et al. (2013) have described that feeding rate was also a limiting factor for fish growth. Feeding frequency is one of the most important variables influencing growth performance and feed conversion ratio in aquaculture husbandry practices (Kim et al., 2007; Biswas et al., 2010; Lee and Pham, 2010).

Several studies have been conducted to evaluate the effect of feeding frequency on growth, survival, feed utilization and body composition in different fish species including Korean rock fish (Lee et al., 2000), yellowtail flounder (Dwyer et al., 2002), ayu (Cho et al., 2003); Atlantic halibut (Schnaittacher et al., 2005), Indian major carps (Biswas et al., 2006), tambaqui (Silva et al., 2007); Australian snapper (Booth et al., 2008), and pike perch (Wang et al., 2009).

The optimal feeding frequency improves fish growth, survival and feed conversion ratio, and also reduces size variation and environmental pollution (Tucker et al., 2006; Xie et al., 2011). Excessive feeding leads not only to reduction in feed conversion efficiency and increase in input cost, but also to accumulation of wastes that adversely affects the water quality deterioration. On the other hand, sporadic feeding frequency may lead to increase hunger, intra-specific aggression and increased rate of cannibalism (Folkvord and Ottera, 1993). All these problems result in decreased production efficiency and in increased cost of production (Booth et al., 2008). However, available data are limited concerning optimal feeding frequency with optimum water temperature to maximize growth in growing Korean rockfish. Therefore, the objective of this study was to determine the optimum feeding frequency in growing Korean rockfish rearing at the temperature of $15^{\circ} \mathrm{C}$ and $19^{\circ} \mathrm{C}$.

\section{MATERIALS AND METHODS}

\section{Experimental diet}

Commercial extruded feed was used in the feeding trial which was supplied by Suhyup Feed Company Limited (Uiryeong, Gyeongsangnamdo, Republic of Korea). The extruded pellet size was $5 \mathrm{~mm}$ and the feed contained $52.95 \%$ crude protein, $12.14 \%$ crude lipid, $13.75 \%$ crude ash and $9.45 \%$ moisture.

\section{Experimental fish and feeding trial}

Growing Korean rockfish were collected from a hatchery of Tongyeong coastal city and they were transported to the Department of Fisheries Biology of Pukyong National University, Busan, Republic of Korea. Prior to start of the experiment, fish were acclimated with the experimental diet and conditions. After acclimatization, three aquaria were selected to determine the satiation. Fish were fed three times a day to apparent satiation for a week.
For satiation, fish were fed as much as they could ingest at each feeding time. Feeding was done by hand very slowly and carefully to ensure ingestion of feed completely. Finally the remaining feed weight was subtracted from the initial weight and calculated as the percentage of satiation.

After the conditioning period, fifteen fish averaging $92.2 \pm 0.7 \mathrm{~g}$ (mean \pm standard deviation $[\mathrm{SD}])$ at $15.0 \pm 0.5^{\circ} \mathrm{C}$ and $100.2 \pm 0.4 \mathrm{~g} \quad($ mean $\pm \mathrm{SD})$ at $19.0 \pm 0.5^{\circ} \mathrm{C}$ water temperatures were randomly distributed into each of 15 indoor tanks. Each tank was then randomly assigned to one of three replicated groups. A total of five feeding frequency groups were set up as follows: one meal a day at 08:00 hour, two meals a day at 08:00 and 17:00 hours, three meals a day at 08:00, 14:00, and 20:00 hours, four meals a day at 08:00, 12:00, 16:00, and 20:00 hours, and one meal every 2 days at 08:00 hour. Fish were fed by the feeding rate at $1.2 \%$ body weight $(\mathrm{BW}) / \mathrm{d}$ at $15^{\circ} \mathrm{C}$ and $1.5 \% \mathrm{BW} / \mathrm{d}$ at $19^{\circ} \mathrm{C}$. The feeding trial was conducted in a semi-recirculation system with 250-L rectangular tank receiving filtered seawater $(33.0 \pm 0.5 \mathrm{ppt})$ supplied at a flow rate of $5 \mathrm{~L} / \mathrm{min}$ from the central tank. Supplemental aerations were provided to maintain dissolved oxygen levels near $6.5 \pm 0.5 \mathrm{mg} / \mathrm{L}$. Seawater temperature was maintained at $19.0 \pm 0.5^{\circ} \mathrm{C}$ and $15.0 \pm 0.5^{\circ} \mathrm{C}$ by using water heater and cooling machine in the center tank during the whole experimental period. Photo period was fixed at a natural condition during the feeding period. Total body weight of fish in each tank was determined every 4 weeks, and the amounts of diet fed were adjusted accordingly to the increasing body weight in the trial. In order to maintain a good environmental condition siphoning was carried out twice a day and around $50 \%$ to $60 \%$ water was changed every 2 days from the recirculation system.

\section{Sample collection and analyses}

After 8 weeks of feeding trial, fish were kept starved for $24 \mathrm{~h}$ and they were counted and weighed. Weight gain (WG), specific growth rate (SGR), feed efficiency (FE), protein efficiency ratio (PER), survival and whole body proximate composition were measured and calculated. At the end of feeding trial, total length and total body weight were measured from five randomly selected fish from each tank. And those fish were anesthetized with MS222 at a concentration of $100 \mathrm{mg} / \mathrm{L}$ and fish were dissected and measured their liver and visceral weight to determine the biological indices such as condition factor (CF), hepatosomatic index (HSI), and visceral somatic index (VSI). Blood samples were taken by using a heparinized syringes from the caudal vein of five randomly chosen fish per tank and then blood analysis was performed to get some parameters. Blood serum was collected after centrifugation (3,000 $\mathrm{rpm}$ for $10 \mathrm{~min})$ and stored at $-70^{\circ} \mathrm{C}$ in order to analyze the hematocrit (HCT), hemoglobin $(\mathrm{Hb})$, glutamic 
oxaloacetic transaminase (GOT) and glutamic pyruvic transaminase (GPT). The HCT and Hb were measured using the Drabkin's reagent method (Brown, 1980). Blood serum analyses were performed by the National Fisheries Research and Development Institute (NFRDI), Gijang-Gun, Busan, Korea. NFRDI analyzed blood serum using the kits of DRI-CHEM 4000i- Fuji Dri-Chem Slide-3150 (Tokyo, Japan). Rest five fish from each tank were used to analyze the whole-body proximate composition. Proximate composition analyses of experimental diets and fish body were performed by the standard methods of AOAC (1995). To determine the moisture content a number of samples of diets and fish were dried to maintain constant weights at $105^{\circ} \mathrm{C}$ for $24 \mathrm{~h}$. Ash content was determined using a muffle furnace $\left(550^{\circ} \mathrm{C}\right.$ for $\left.4 \mathrm{~h}\right)$. Crude fat content was determined by the soxhlet extraction method by using Soxtec system 1046 (Foss, Hoganas, Sweden) and crude protein content by Kjeldahl method $(N \times 6.25)$ after acid digestion.

\section{Statistical analyses}

All data were subjected to one-way analysis of variance (Statistics 3.1, Analytical Software, St. Paul, MN, USA). A least significant difference test was used to compare means amongst treatments with significant effects. Treatment effects were considered with the significant level at $\mathrm{p}<0.05$. The data are presented as mean \pm standard error of the mean of the replicate groups ( 3 tanks per treatment).

The effects of feeding rates on growth performance and body composition were assessed by the following formulae:

Satiation (SA: \% BW/d)
$=$ total feed weight $(\mathrm{g}) \times 100 /$ total fish weight $(\mathrm{g})$

$\mathrm{WG}$ rate $=($ final weight - initial weight $)$ $\times 100 /$ initial weight

$\operatorname{SGR}(\% / d)=\left(\log _{\mathrm{e}}\right.$ final $w t-\log _{\mathrm{e}}$ initial $\left.w t\right) \times 100 /$ days

FE $(\%)=$ wet WG $(\mathrm{g}) \times 100 /$ dry feed intake $(\mathrm{g})$

$\mathrm{PER}=$ wet $\mathrm{WG} /$ protein intake

$\mathrm{CF}=$ fish weight $(\mathrm{g}) \times 100 /$ total length $\left(\mathrm{cm}^{3}\right)$

HSI = liver weight $(\mathrm{g}) \times 100 /$ fish weight $(\mathrm{g})$

Visceralsomatic index

$=$ visceral weight $\times 100 /$ fish weight $(\mathrm{g})$

Pooled SEM: pooled standard error of means

Survival (\%)

$=$ number of fish at end of experiment

/number of fish stocked $\times 100$

\section{RESULTS}

\section{Feeding frequency of $92 \mathrm{~g}$ Korean rockfish reared at $15^{\circ} \mathrm{C}$}

Weight gain, SGR, FE, and PER of fish, reared at $15^{\circ} \mathrm{C}$ water temperature are presented in Table 1 . Weight gain was significantly affected by feeding frequency. At the end of 8

Table 1. Biological performance and morphological indices of $92 \mathrm{~g}$ Korean rockfish, reared at $15^{\circ} \mathrm{C}$ water temperature

\begin{tabular}{|c|c|c|c|c|c|c|c|}
\hline \multirow[b]{2}{*}{ Items } & \multicolumn{7}{|c|}{ Feeding frequency } \\
\hline & 1 meal/day & 2 meals/day & 3 meals/day & 4 meals/day & $\begin{array}{c}1 \text { meal } / 2 \text { days } \\
\left(\mathrm{SA}^{1}\right)\end{array}$ & $\mathrm{p}$ value & Pooled SEM ${ }^{2}$ \\
\hline$\overline{\mathrm{WG}^{3}}$ & $44.53^{\mathrm{a}}$ & $42.36^{\mathrm{a}}$ & $30.93^{\mathrm{b}}$ & $29.96^{\mathrm{b}}$ & $27.33^{b}$ & $<0.05$ & 2.13 \\
\hline $\mathrm{SGR}^{4}$ & $0.75^{\mathrm{a}}$ & $0.72^{\mathrm{a}}$ & $0.53^{\mathrm{b}}$ & $0.52^{\mathrm{b}}$ & $0.49^{\mathrm{b}}$ & $<0.05$ & 0.03 \\
\hline $\mathrm{FE}^{5}$ & $81.55^{\mathrm{a}}$ & $77.51^{\mathrm{a}}$ & $55.75^{\mathrm{b}}$ & $53.85^{\mathrm{b}}$ & $81.89^{\mathrm{a}}$ & $<0.05$ & 3.79 \\
\hline $\mathrm{PER}^{6}$ & $1.61^{\mathrm{a}}$ & $1.53^{\mathrm{a}}$ & $1.10^{\mathrm{b}}$ & $1.06^{\mathrm{b}}$ & $1.61^{\mathrm{a}}$ & $<0.05$ & 0.07 \\
\hline $\mathrm{FI}^{7}$ & $50.5^{\mathrm{a}}$ & $50.3^{\mathrm{a}}$ & $49.5^{\mathrm{a}}$ & $49.4^{\mathrm{a}}$ & $30.7^{\mathrm{b}}$ & $<0.05$ & 2.07 \\
\hline Survival $^{8}$ & 100 & 100 & 100 & 100 & 100 & $>0.05$ & 0 \\
\hline \multicolumn{8}{|c|}{ Morphological indices } \\
\hline $\mathrm{CF}^{9}$ & $1.37^{\mathrm{a}}$ & $1.35^{\mathrm{a}}$ & $1.33^{\mathrm{ab}}$ & $1.32^{\mathrm{ab}}$ & $1.23^{\mathrm{b}}$ & $<0.05$ & 0.02 \\
\hline $\mathrm{HSI}^{10}$ & $2.84^{b}$ & $3.06^{\mathrm{a}}$ & $3.03^{\mathrm{a}}$ & $2.93^{\mathrm{a}}$ & $2.70^{\mathrm{c}}$ & $<0.05$ & 0.05 \\
\hline $\mathrm{VSI}^{11}$ & $13.77^{b}$ & $14.35^{\mathrm{a}}$ & $12.92^{\mathrm{ab}}$ & $11.10^{\mathrm{c}}$ & $11.31^{\mathrm{c}}$ & $<0.05$ & 0.49 \\
\hline
\end{tabular}

SA, satiation; Pooled SEM, pooled standard error of means; WG, weight gain; SGR, specific growth rate; FE, feed efficiency; PER, protein efficiency ratio; FI, feed intake; CF, condition factor; HSI, hepatosomatic index; VSI, Visceral somatic index.

${ }^{1} \mathrm{SA}(1.3 \%)=$ total feed weight $(\mathrm{g}) \times 100 /$ total fish weight $(\mathrm{g}) .{ }^{2} \mathrm{SD} / \sqrt{\mathrm{n}} \cdot{ }^{3} \mathrm{WG}(\%)=($ final weight - initial weight $) \times 100 /$ initial weight.

${ }^{4} \mathrm{SGR}(\% / \mathrm{d})=100 \times\left(\log _{\mathrm{e}}\right.$ final wt $-\log _{\mathrm{e}}$ initial wt $) /$ days. ${ }^{5} \mathrm{FE}(\%)=$ wet weight gain $(\mathrm{g}) \times 100 /$ dry feed intake $(\mathrm{g})$.

${ }^{6} \mathrm{PER}=$ wet weight gain/protein intake. ${ }^{7} \mathrm{FI}=($ final weight - initial weight $) /$ feed efficiency.

${ }^{8}$ Survival $(\%)=$ number of fish at end of experiment $\times 100 /$ number of fish stocked. ${ }^{9} \mathrm{CF}=$ fish weight $(\mathrm{g}) \times 100 /$ total length $\left(\mathrm{cm}^{3}\right)$.

${ }^{10} \mathrm{HSI}=$ liver weight $(\mathrm{g}) \times 100 /$ fish weight $(\mathrm{g}) .{ }^{11} \mathrm{VSI}=$ visceral weight $\times 100 /$ fish weight $(\mathrm{g})$.

Values are means from triplicate groups of fish where the values in each row with different superscripts are significantly different $(\mathrm{p}<0.05)$.

${ }^{a}, b, c$ Within a row, mean without a common letters $(a, b$, and $c)$ differ $(\mathrm{p}<0.05)$. 
wks of feeding trial WG and SGR of fish groups of one meal a day and two meals a day were significantly higher than those of other fish groups $(\mathrm{p}<0.05)$. No significant differences were found in these parameters among the fish fed groups at 3 meals a day, 4 meals a day and 1 meal every 2 days. The FE and PER of fish fed 1 meal a day, 2 meals a day and 1 meal every two days were significantly higher than those fed 3 meals a day and 4 meals a day. There were no significant differences in FE and PER between fish groups fed 3 meals a day and 4 meals a day. Survival rate (SR) was not affected by feeding frequency.

Morphological indices were significantly affected by feeding frequency (Table 1). Hepatosomatic index and VSI was significantly higher in 2 meals a day group and significantly lower in 1 meal every 2 days group. Condition factor in 1 meal a day and 2 meals a day groups were significantly higher than in all other fish groups. The CF was gradually decreased as feeding frequency increased from 2 to 4 meals a day. There were no significant differences in CF between the fish groups of 1 meal a day and 2 meals a day. And HSI had no any significant differences among the fish groups of 2 meals a day, 3 meals a day and 4 meals a day and it was significantly higher than other groups.

Whole body proximate compositions of rockfish are depicted in Table 2. Protein and fat contents were significantly higher in 1 meal a day and significantly lower in fish groups fed 4 meals a day and 1 meal every 2 days. An increase in feeding frequency resulted in a decrease in protein and fat (Figures 5 and 6). There was no significant difference in ash content at different feeding frequency. Whole-body moisture and crude ash content of fish were significantly higher at the group of 2 meals a day. And these parameters were comparatively lower at the group of 4 meals a day.
Effects of feeding frequency on serological characteristics of growing Korean rockfish, reared at $15^{\circ} \mathrm{C}$ water temperature are presented at Table 2. Hematocrit of fish fed group at 1 meal a day was significantly higher than other fish fed groups. There were no significant differences in HCT among the fish fed groups of 2 meals a day, 4 meals a day and 1 meal every 2 days. Hemoglobin had no any significant difference among all the fish fed groups. Glutamic oxaloacetic transaminase and GPT were significantly affected by feeding frequency. Serum GPT and GOT of fish fed group at 1 meal every 2 days was significantly higher and fish fed groups at 1 meal a day and 2 meals a day were significantly lower than all other fish fed groups. There was a clear trend in GPT and GPT with feeding frequency, because GOT and GPT were increased as the increasing of feeding frequency. There was no significant difference in GPT among the fish fed groups at 3 meals a day and 4 meals a day and also no significant difference in GOT was found among the fish fed groups at 1 meal a day, 2 meals a day.

\section{Feeding frequency of $100 \mathrm{~g}$ growing Korean rockfish reared at $19^{\circ} \mathrm{C}$}

Weight gain and SGR, FE, PER of $100 \mathrm{~g}$ size of Korean rockfish, reared at $19^{\circ} \mathrm{C}$ water temperature are shown in Table 3 . Weight gain was significantly affected by feeding frequency. At the end of 8 wks of feeding trial WG and SGR of fish fed group of one meal per two days was significantly lower than those of other fish fed groups $(p<0.05)$. No significant differences were found in these parameters among fish fed groups at 1 meal a day, 2 meals a day, 3 meals a day and 4 meals a day. Feed efficiency and PER of fish fed group at 1 meal every 2 days were significantly higher than those of other fish fed groups. There were no significant differences in FE and PER at the

Table 2. Whole-body proximate composition and serological characteristics of $92 \mathrm{~g}$ Korean rockfish, reared at $15^{\circ} \mathrm{C}$ water temperature

\begin{tabular}{|c|c|c|c|c|c|c|c|}
\hline \multirow[b]{2}{*}{ Items } & \multicolumn{7}{|c|}{ Feeding frequency } \\
\hline & 1 meal/day & 2 meals/day & 3 meals/day & 4 meals/day & $\begin{array}{c}1 \text { meal } / 2 \text { days } \\
\left(\mathrm{SA}^{1}\right)\end{array}$ & $\mathrm{p}$ value & $\begin{array}{l}\text { Pooled } \\
\text { SEM }^{2}\end{array}$ \\
\hline Crude protein & $55.4^{\mathrm{a}}$ & $55.2^{\mathrm{a}}$ & $54.8^{\mathrm{ab}}$ & $53.6^{\mathrm{b}}$ & $53.4^{\mathrm{b}}$ & $<0.05$ & 0.27 \\
\hline Crude lipid & $34.3^{\mathrm{a}}$ & $33.3^{\mathrm{ab}}$ & $33.0^{\mathrm{ab}}$ & $32.7^{\mathrm{b}}$ & $32.0^{\mathrm{b}}$ & $<0.05$ & 0.41 \\
\hline Crude ash & 10.6 & 11.1 & 10.9 & 10.5 & 10.9 & $<0.05$ & 0.15 \\
\hline Moisture & $69.9^{\mathrm{b}}$ & $72.4^{\mathrm{a}}$ & $70.6^{\mathrm{ab}}$ & $69.8^{\mathrm{b}}$ & $70.0^{\mathrm{b}}$ & $<0.05$ & 0.39 \\
\hline \multicolumn{8}{|c|}{ Serological characteristics } \\
\hline $\mathrm{HCT}(\%)$ & $36.11^{\mathrm{a}}$ & $35.10^{\mathrm{b}}$ & $35.70^{\mathrm{ab}}$ & $35.10^{\mathrm{b}}$ & $35.11^{\mathrm{b}}$ & $<0.05$ & 0.24 \\
\hline $\mathrm{Hb}(\mathrm{g} / \mathrm{dL})$ & 6.80 & 6.93 & 6.80 & 6.57 & 6.23 & $>0.05$ & 0.18 \\
\hline GOT (IU/L) & $10.70^{\mathrm{c}}$ & $10.70^{\mathrm{c}}$ & $12.73^{\mathrm{b}}$ & $13.83^{\mathrm{ab}}$ & $15.72^{\mathrm{a}}$ & $<0.05$ & 1.09 \\
\hline GPT (IU/L) & $3.70^{\mathrm{b}}$ & $3.71^{\mathrm{b}}$ & $4.10^{\mathrm{ab}}$ & $4.20^{\mathrm{ab}}$ & $4.50^{\mathrm{a}}$ & $<0.05$ & 0.20 \\
\hline
\end{tabular}

SA, satiation; Pooled SEM, pooled standard error of means; HCT, Hematocrit; Hb, hemoglobin; GOT, glutamic oxaloacetic transaminase; GPT, glutamic pyruvic transaminase.

${ }^{1} \mathrm{SA}(1.3 \%)=$ total feed weight $(\mathrm{g}) \times 100 /$ total fish weight $(\mathrm{g}) .{ }^{2} \mathrm{SD} / \sqrt{\mathrm{n}}$.

Values are means from triplicate groups of fish where the values in each row with different superscripts are significantly different $(\mathrm{p}<0.05)$.

${ }^{a, b}, c$ Within a row, mean without a common letters $(a, b$, and $c)$ differ $(p<0.05)$. 
Table 3. Biological performance and morphological indices of $100 \mathrm{~g}$ Korean rockfish, reared at $19^{\circ} \mathrm{C}$ water temperature

\begin{tabular}{|c|c|c|c|c|c|c|c|}
\hline \multirow[b]{2}{*}{ Items } & \multicolumn{7}{|c|}{ Feeding frequency } \\
\hline & 1meal/day & 2 meals/day & 3 meals/day & 4 meals/day & $\begin{array}{c}1 \mathrm{meal} / 2 \text { days } \\
\left(\mathrm{SA}^{1}\right)\end{array}$ & $\mathrm{p}$ value & $\begin{array}{r}\text { Pooled } \\
\text { SEM }^{2}\end{array}$ \\
\hline$\overline{\mathrm{WG}^{3}}$ & $31.82^{\mathrm{a}}$ & $32.12^{\mathrm{a}}$ & $30.33^{\mathrm{a}}$ & $29.24^{\mathrm{a}}$ & $17.87^{\mathrm{b}}$ & $<0.05$ & 1.61 \\
\hline $\mathrm{SGR}^{4}$ & $0.52^{\mathrm{a}}$ & $0.52^{\mathrm{a}}$ & $0.50^{\mathrm{a}}$ & $0.50^{\mathrm{a}}$ & $0.31^{\mathrm{b}}$ & $<0.05$ & 0.22 \\
\hline $\mathrm{FE}^{5}$ & $40.85^{\mathrm{b}}$ & $41.94^{\mathrm{ab}}$ & $39.45^{\mathrm{b}}$ & $39.36^{\mathrm{b}}$ & $43.14^{\mathrm{a}}$ & $<0.05$ & 1.10 \\
\hline PER $^{6}$ & $0.81 \mathrm{a}^{\mathrm{b}}$ & $0.83^{\mathrm{ab}}$ & $0.78^{\mathrm{b}}$ & $0.78^{\mathrm{b}}$ & $0.85^{\mathrm{a}}$ & $<0.05$ & 0.02 \\
\hline $\mathrm{FI}^{7}$ & $78.1^{\mathrm{a}}$ & $76.9^{\mathrm{ab}}$ & $77.2^{\mathrm{ab}}$ & $75.9^{\mathrm{b}}$ & $41.6^{\mathrm{c}}$ & $<0.05$ & 3.80 \\
\hline Survival $^{8}$ & 100 & 100 & 100 & 100 & 100 & $>0.05$ & 0 \\
\hline \multicolumn{8}{|c|}{ Morphological indices } \\
\hline $\mathrm{CF}^{9}$ & $1.31^{\mathrm{a}}$ & $1.22^{\mathrm{b}}$ & $1.21^{\mathrm{b}}$ & $1.20^{\mathrm{b}}$ & $1.10^{\mathrm{b}}$ & $<0.05$ & 0.03 \\
\hline $\mathrm{HSI}^{10}$ & $2.78^{\mathrm{a}}$ & $2.68^{\mathrm{ab}}$ & $2.66^{\mathrm{ab}}$ & $2.58^{\mathrm{b}}$ & $2.37^{\mathrm{c}}$ & $<0.05$ & 0.17 \\
\hline $\mathrm{VSI}^{11}$ & $10.83^{\mathrm{a}}$ & $10.39^{\mathrm{ab}}$ & $10.18^{\mathrm{b}}$ & $10.13^{\mathrm{b}}$ & $10.12^{\mathrm{b}}$ & $<0.05$ & 0.37 \\
\hline
\end{tabular}

SA, satiation; Pooled SEM, pooled standard error of means; WG, weight gain; SGR, specific growth rate; FE, feed efficiency; PER, protein efficiency ratio; FI, feed intake; CF, condition factor; HSI, hepatosomatic index; VSI, Visceral somatic index.

${ }^{1} \mathrm{SA}(1.5 \%)=$ total feed weight $(\mathrm{g}) \times 100 /$ total fish weight $(\mathrm{g}) .{ }^{2} \mathrm{SD} / \sqrt{\mathrm{n}}$.

${ }^{3} \mathrm{WG}(\%)=($ final weight - initial weight $) \times 100 /$ initial weight. ${ }^{4}$ SGR $(\% / \mathrm{d})=100 \times\left(\log _{\mathrm{e}}\right.$ final wt $-\log _{\mathrm{e}}$ initial wt $) /$ days .

${ }^{5} \mathrm{FE}(\%)=$ wet weight gain $(\mathrm{g}) \times 100 /$ dry feed intake $(\mathrm{g}) .{ }^{6} \mathrm{PER}=$ wet weight gain/protein intake.

${ }^{7}$ Feed intake $=($ final weight - initial weight $) /$ feed efficiency. ${ }^{8}$ Survival $(\%)=$ number of fish at end of experiment $\times 100 /$ number of fish stocked.

${ }^{9} \mathrm{CF}=$ fish weight $(\mathrm{g}) \times 100 /$ total length $\left(\mathrm{cm}^{3}\right) .{ }^{10} \mathrm{HSI}=$ liver weight $(\mathrm{g}) \times 100 /$ fish weight $(\mathrm{g}) .{ }^{11} \mathrm{VSI}=$ visceral weight $\times 100 /$ fish weight $(\mathrm{g})$.

Values are means from triplicate groups of fish where the values in each row with different superscripts are significantly different $(\mathrm{p}<0.05)$.

${ }^{\mathrm{a}, \mathrm{b}, \mathrm{c}}$ Within a row, mean without a common letters $(\mathrm{a}, \mathrm{b}$, and $\mathrm{c})$ differ $(\mathrm{p}<0.05)$

fish fed groups of 1 meal a day, 3 meals a day and 4 meals a day. Survival rate was not affected by feeding frequency.

Effects of feeding frequency on morphological indices of $100 \mathrm{~g}$ size of Korean rockfish, reared at $19^{\circ} \mathrm{C}$ water temperature are shown in Table 3. Morphological indices were significantly affected by feeding frequency. Condition factor, HSI and VSI of fish fed group at 1 meal a day was significantly higher and at 1 meal every 2 days group was significantly lower of than those of other fish fed groups. There was a trend on morphological indices with feeding frequency because CF, HSI, and VSI were gradually decreased with the increasing of feeding frequency. There were no significant differences in HSI among the fish fed groups of 2 meals a day and 3 meals a day and also HSI did not express any significant differences among the fish fed groups of 3 meals a day, 4 meals a day and 1 meal every 2 days.

Whole-body proximate composition of growing Korean rockfish, reared at $19^{\circ} \mathrm{C}$ water temperature is presented at Table 4. Whole-body protein and lipid contents were significantly higher at 1 meal a day and it was significantly lower at the fish fed group of 4 meals a day. In the present study, there were clear trends with feeding frequency among whole-body crude protein and crude lipid because it

Table 4. Whole-body proximate composition and serological characteristics of $100 \mathrm{~g}$ Korean rockfish, reared at $19^{\circ} \mathrm{C}$ water temperature

\begin{tabular}{lccccccc}
\hline & \multicolumn{7}{c}{ Feeding frequency } \\
\cline { 2 - 7 } Items & 1 meal/day & 2 meals/day & 3 meals/day & 4 meals/day & $\begin{array}{c}1 \text { meal/2 days } \\
\left(\mathrm{SA}^{1}\right)\end{array}$ & $\begin{array}{c}\text { p value } \\
\text { SEM }\end{array}$ \\
\hline Crude protein & $54.74^{\mathrm{a}}$ & $54.12^{\mathrm{a}}$ & $52.71^{\mathrm{b}}$ & $52.64^{\mathrm{b}}$ & $51.12^{\mathrm{c}}$ & $<0.05$ & 0.33 \\
Crude lipid & $37.63^{\mathrm{a}}$ & $35.63^{\mathrm{b}}$ & $31.65^{\mathrm{c}}$ & $30.76^{\mathrm{c}}$ & $30.12^{\mathrm{c}}$ & $<0.05$ & 0.94 \\
Crude ash & $12.52^{\mathrm{a}}$ & $10.80^{\mathrm{c}}$ & $12.92^{\mathrm{a}}$ & $11.00^{\mathrm{b}}$ & $11.40^{\mathrm{ab}}$ & $<0.05$ & 0.63 \\
Moisture & $67.62^{\mathrm{ab}}$ & $68.11^{\mathrm{a}}$ & $66.81^{\mathrm{b}}$ & $68.92^{\mathrm{a}}$ & $68.41^{\mathrm{a}}$ & $<0.05$ & 0.32 \\
Serological characteristics & & & & & & \\
HCT (\%) & $33.92^{\mathrm{c}}$ & $35.56^{\mathrm{b}}$ & $36.51^{\mathrm{a}}$ & $33.82^{\mathrm{c}}$ & $35.83^{\mathrm{b}}$ & $<0.05$ & 0.83 \\
Hb (g/dL) & $7.90^{\mathrm{b}}$ & $8.11^{\mathrm{b}}$ & $8.50^{\mathrm{a}}$ & $7.90^{\mathrm{b}}$ & $8.80^{\mathrm{a}}$ & $<0.05$ & 0.19 \\
GOT (IU/L) & $20.03^{\mathrm{b}}$ & $20.64^{\mathrm{ab}}$ & $20.72^{\mathrm{ab}}$ & $22.76^{\mathrm{a}}$ & $22.32^{\mathrm{a}}$ & $<0.05$ & 0.48 \\
GPT (IU/L) & $6.40^{\mathrm{b}}$ & $6.57^{\mathrm{ab}}$ & $6.93^{\mathrm{a}}$ & $6.90^{\mathrm{a}}$ & $6.97^{\mathrm{a}}$ & $<0.05$ & 0.19 \\
\hline
\end{tabular}

SA, satiation; Pooled SEM, pooled standard error of means; HCT, Hematocrit; Hb, hemoglobin; GOT, glutamic oxaloacetic transaminase; GPT, glutamic pyruvic transaminase.

${ }^{1} \mathrm{SA}(1.3 \%)=$ total feed weight $(\mathrm{g}) \times 100 /$ total fish weight $(\mathrm{g}) .{ }^{2} \mathrm{SD} / \sqrt{\mathrm{n}}$.

Values are means from triplicate groups of fish where the values in each row with different superscripts are significantly different $(\mathrm{p}<0.05)$.

${ }^{a, b, c}$ Within a row, mean without a common letters $(a, b$, and $c)$ differ $(\mathrm{p}<0.05)$ 
was gradually decreasing with the increasing of feeding frequency from 1 to 4 meals a day. But this relation was not found in whole-body moisture and crude ash content of fish. On other hand, whole-body moisture at 3 meals a day and crude ash content at 2 meals a day were significantly lower than those of all other feeding frequency groups.

Effects of feeding frequency on serological characteristics of $100 \mathrm{~g}$ growing Korean Rockfish, reared at $19^{\circ} \mathrm{C}$ water temperature are depicted in Table 4. Hematocrit of fish fed group at 3 meals a day and $\mathrm{Hb}$ at 1 meal every 2 days were significantly higher than other fish fed groups. There were no significant differences in HCT among the fish fed groups of 1 meal a day and 4 meals a day and $\mathrm{Hb}$ was not found any significant difference among the fish fed groups of 3 meals a day and 1 meal every 2 days. Glutamic oxaloacetic transaminase and GPT were significantly affected by feeding frequency. There was a clear trend in GPT and GPT with feeding frequency, because GOT and GPT were increased as the increasing of feeding frequency. Serum GOT and GPT of fish fed group at 1 meal a day was significantly lower and it was significantly higher at the fish fed groups of 4 meals a day and 1 meal every 2 days. There was no significant difference of GOT among the fish fed groups at 2 meals a day and 3 meals a day and also no significant difference found in GPT among the fish fed groups at 3 meals a day, 4 meals a day and 1 meal a day and it was significantly higher.

\section{DISCUSSION}

In the present study, WG and SGR at 1 meal a day and 2 meals a day were significantly higher than all other fish feeding frequency groups in $15^{\circ} \mathrm{C}$ and at the fish fed group of 1 meal every 2 days was significantly lower in both 15 and $19^{\circ} \mathrm{C}$ experiments. Weight gain and SGR were gradually decreased with the increasing of feeding frequency in both experiments (Tables 1 and 3). Growth performance was comparatively higher at $15^{\circ} \mathrm{C}$ than $19^{\circ} \mathrm{C}$ experiment (Figure 1). Fish growth was not significantly enhanced by increasing the number of meals from 2 to 4 meals per day. Because when the feeding frequency high or the intervals between meals is short, the food passes through the digestive tract more quickly, resulting in less effective digestion. This agreement also well established with some previous research findings reported by Van Ham et al. (2003) and Biswas et al. (2010). Feed efficiency and PER of fish fed at 1 meal a day and 2 meals a day were significantly higher than fish fed groups of 3 meals a day and 4 meals a day. Because, fish tend to optimize their digestion to extract nutrients more efficiently at the optimum feeding rate (Van Ham et al., 2003). Feed consumption and growth increased linearly with an increase in the feeding frequency up to a certain level in juvenile

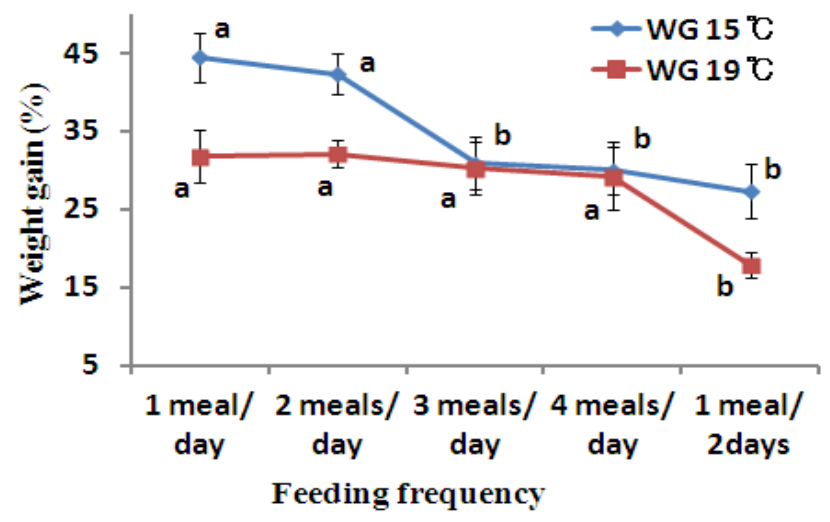

Figure 1. Weight gain of rockfish with different feeding frequencies at $15^{\circ} \mathrm{C}$ and $19^{\circ} \mathrm{C}$.

black sea turbot (Aydin et al., 2011). Over-feeding not only reduces the feed conversion efficiency, but also accumulates lots of waste that adversely affects the water quality (Biswas et al., 2006). Our previous study described that after the optimum feeding, fish could not efficiently utilize additional feeds, leading to the drop in FE and PER in juvenile Korean rockfish (Mizanur and Bai, 2014; Mizanur et al., 2014a,b) and juvenile olive flounder (Okorie et al., 2013).

Hepatosomatic index, CSI, and CF may provide the information on growth, physical condition, energy reserves and ability of fish to tolerate the environmental stresses. In a poor, stressful and unfavorable environment, fish usually have a smaller liver which means less energy reserved in the liver. In the present study, morphological indices were significantly affected by feeding frequency. Condition factor, HSI and VSI were significantly higher at the group of 2 meals a day in $15^{\circ} \mathrm{C}$ and at 1 meal a day group in $19^{\circ} \mathrm{C}$. On the other hand, $\mathrm{CF}$ and HSI were comparatively higher at $15^{\circ} \mathrm{C}$ than $19^{\circ} \mathrm{C}$ experiment (Figure 2; Tables 1 and 3). Condition factor, HSI and VSI were gradually decreased as the increasing of feeding frequency. It might be happened

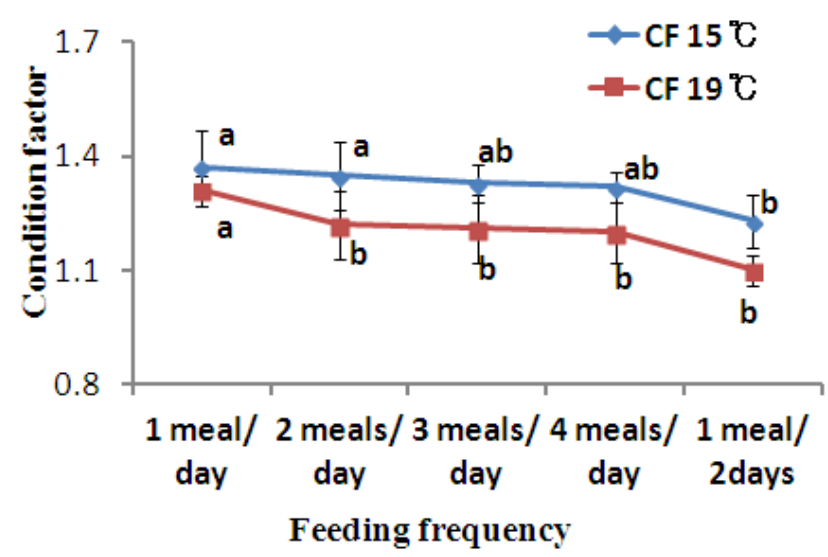

Figure 2. Condition factor of rockfish with different feeding frequencies at $15^{\circ} \mathrm{C}$ and $19^{\circ} \mathrm{C}$. 


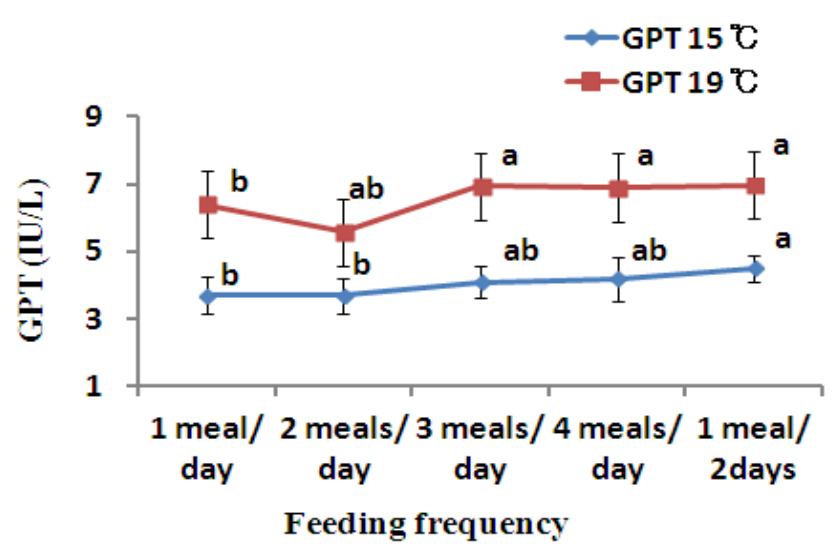

Figure 3. Glutamic pyruvic transaminase of rockfish with different feeding frequencies at $15^{\circ} \mathrm{C}$ and $19^{\circ} \mathrm{C}$.

because of environmental pollution due to higher feeding frequency and fish could not able to digest properly all the feeds. Condition factor, HSI, and VSI at 1 meal every 2 days group was significantly lower than other fish fed groups in both experiments. Because, Korean rockfish was might be always hungry and under feeding stressed conditions. Oh et al. (2008) have described that HSI is a good compensatory growth index in juvenile black rockfish. On the other hand, HSI and CF of olive flounder could be indices reflecting the compensatory growth has been indicated by Cho (2012).

Whole-body proximate composition of Korean rockfish was determined to know the optimum feeding frequency at two different water temperatures. Whole-body protein and lipid contents were significantly higher at 1 meal per day and it was significantly lower at the fish fed group of 4 meals a day in both experiments. Crude protein and crude lipid were decreased as the increasing of feeding frequency. Van Ham et al. (2003) have got the same results in turbot fish. Lipid content of fish related to dietary energy level, indicating that excess dietary energy is not utilized by fish growth; it is deposited as lipid (Lee and Pham, 2010). On the other hand, less energy was used to compete for food

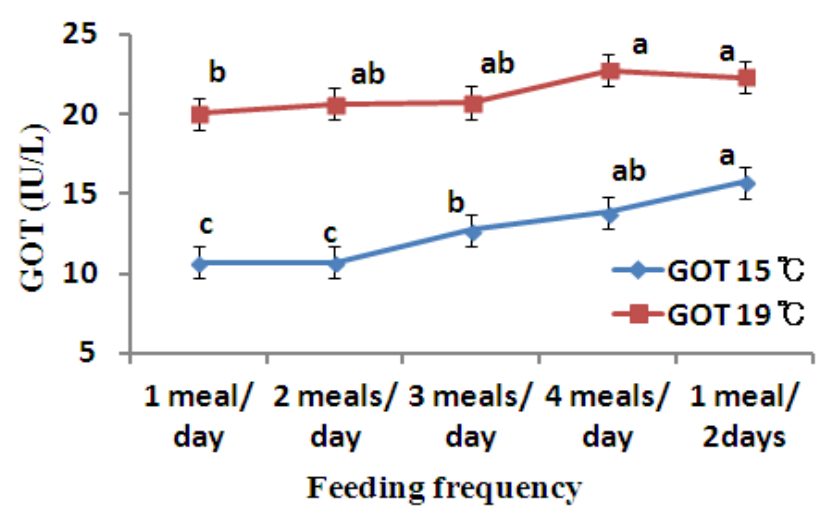

Figure 4. Glutamic oxaloacetic transaminase of rockfish with different feeding frequencies at $15^{\circ} \mathrm{C}$ and $19^{\circ} \mathrm{C}$.

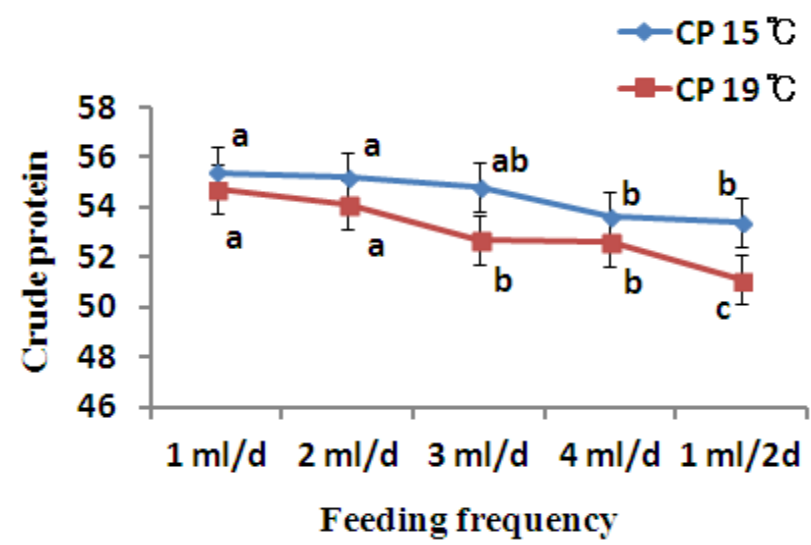

Figure 5. Whole body crude protein of rockfish with different feeding frequencies at $15^{\circ} \mathrm{C}$ and $19^{\circ} \mathrm{C}$.

and avoid cannibalism because of plentiful food at higher feeding frequency, so more protein and lipid were deposited in the fish body (Xie et al., 2011). In the present study, crude lipid and crude protein contents of fish fed group at 1 meal every 2 days was lower than other fish fed groups. Because lower feeding frequency distributed more energy to compete for limited food and to avoid cannibalism, which could accelerate the metabolism of protein and lipid.

In the present study, whole-body crude protein and crude lipid were gradually decreased as the increasing of feeding frequency in both experiments (Figures 5 and 6). But this study has been contrasted with some previous research findings such as; whole-body crude protein and crude lipid content were increased with the increasing of feeding frequency in juvenile red spotted grouper (Kayano et al., 1993) and juvenile Korean rockfish (Lee et al., 2000). These results were contrasted because those researchers were conducted their research with juvenile or larval stages of fish which have high digestive power. These findings also has been proved that for the optimum growth of juvenile or larval fish need higher frequency than growing or bigger size (NRC, 2011).

Plasma transaminase enzymes aspartate

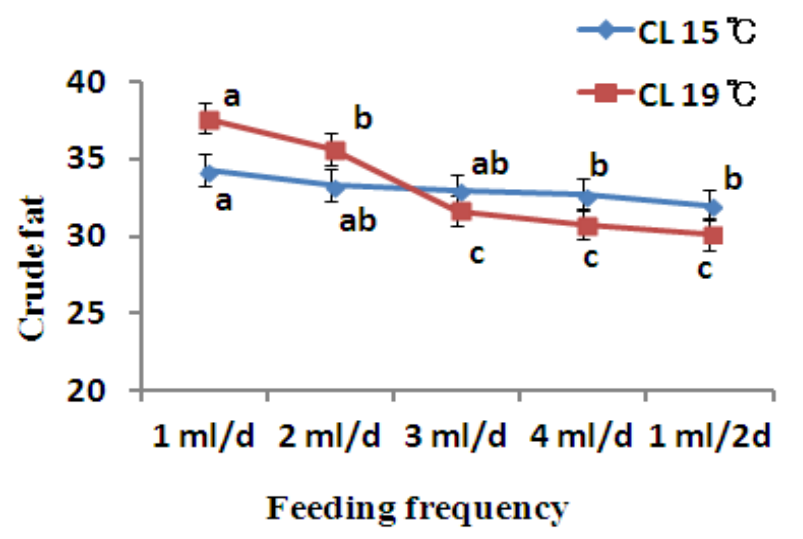

Figure 6. Whole body crude fat of rockfish with different feeding frequencies at $15^{\circ} \mathrm{C}$ and $19^{\circ} \mathrm{C}$. 
aminotransferase and alanine aminotransferase are formerly called GOT and GPT respectively. Serum GPT and GOT ratio provide useful information regarding the extent and causes of liver disease of olive flounder (Qiao et al., 2012). In the present study, serological characteristics of growing Korean rockfish were affected by different feeding frequencies. Serum GPT and GOT were increased with the increasing of feeding frequency in both experiments of $15^{\circ} \mathrm{C}$ and $19^{\circ} \mathrm{C}$. In the present study, GPT and GOT were comparatively lower at $15^{\circ} \mathrm{C}$ than $19^{\circ} \mathrm{C}$ experiment (Figures 3 and 4). Environmental temperature is one of the most important ecological factors which also influence the behavior and physiological process of aquatic animals (Xia and Li, 2010). Glutamic pyruvic transaminase and GOT of fish fed group at 1 meal every 2 days was significantly higher and fish fed group at 1meal a day was significantly lower in both experiments. The reason for this observation may be attributed to the fact that Korean rockfish was might be always hungry and under feeding stressed conditions in 1 meal every 2 days group. Generally, in a stressful and unfavorable environmental condition GPT and GOT increase in blood serum. Serum GPT and GOT were gradually increased with the decreasing of feeding ration in juvenile Korean rockfish (Mizanur et al., 2014a,b) and olive flounder (Cho et al., 2007) due to the stress of under feeding condition.

The optimal feeding frequency for maximum growth of fish varies depending on fish species, sizes and culture conditions (Cho et al., 2003). Among them fish size is the most important factor to determine the optimum feeding frequency. Generally, matured fish need to be fed less frequently and at a lower amount of feed per feeding (NRC, 2011). In the present study there were no significant difference of WG among the fish fed groups at 1 meal a day, 2 meals a day, 3 meals a day and 4 meals a day and it was significantly higher than 1 meal every 2 days group. According to feed and labor cost 1 meal a day would be the optimum feeding frequency for growing Korean rockfish. Seo and Lee (2008) also found that WG of juvenile Korean rockfish fed to satiation once daily was higher than that of fish fed once every 2 days and twice-daily feeding. Feeding frequency of one meal a day till satiation is proper for the improvement of WG in juvenile Korean rockfish has been described by Lee et al. (2000).

\section{CONCLUSION}

In the conclusion, these studies demonstrate that a feeding frequency of 1 meal a day is optimum for the improvement of WG in $92 \mathrm{~g}$ and $100 \mathrm{~g}$ size growing Korean rockfish reared at $15^{\circ} \mathrm{C}$ and $19^{\circ} \mathrm{C}$ water temperatures respectively.

\section{ACKNOWLEDGMENTS}

The authors wish to thanks for the financial support from the National Fisheries Research and Development Institute (RP-2013-AQ-223), Republic of Korea. We would like to express our appreciation to all the students and staffs of the Feeds and Foods Nutrition Research Center (FFNRC) at Pukyong National University who collaborated in different ways while we were conducting our research.

\section{REFERENCES}

AOAC. 1995. Official Methods of Analysis. 16th edn. Association of Official Analytical Chemists, Arlington, VA, USA.

Aydin, I., E. Kucuk, T. Sahin, and L. Kolotoglu. 2011. The effect of feeding frequency and feeding rate on growth performance of juvenile Black Sea Turbot, Psetta maxima (Linneaus, 1758). J. Fishscicom 5:35-42.

Bai, S. C. and O. E. Okorie. 2009. Marine fish. Korean Rockfish (Sebastes schlegeli) Production in Korea. Global Aquaculture Advocate. pp. 41-42.

Biswas, G., J. K. Jena, S. K. Singh, P. Patmajhi, and K. K. Muduli. 2006. Effect of feeding frequency on growth, survival and feed utilization in mrigal (Cirrhinus mrigala) and rohu (Labeo rohita) during nursery rearing. Aquaculture 254:211-218.

Biswas, G., A. R. Thirunavukkarasu, J. K. Sundaray, and M. Kailasam. 2010. Optimization of feeding frequency of Asian seabass (Lates calcarifer) fry reared in net cages under brackishwater environment. Aquaculture 305:26-31.

Bjornsson, B., A. Steinarsson, and T. Arnason. 2007. Growth model for Atlantic cod (Gadus morhua): Effects of temperature and body weight on growth rate. Aquaculture 271216-226.

Booth, M. A., B. J. Tucker, G. L. Allan, and D. Fielder. 2008. Effect of feeding regime and fish size on weight gain, feed intake and gastric evacuation in juvenile Australian snapper (Pagrus auratus). Aquaculture 282:104-110.

Brown, B. A. 1980. Routine hematology procedures. In: Hematology: Principles and Procedures (Eds. Lea and Febiger). Lea and Febiger Co. Philadelphia, USA. pp. 71-112.

Cho, S. H., Y. S. Lim, J. H. Lee, S. Park, and S. M. Lee. 2003. Effect of feeding rate and feeding frequency on survival, growth, and body composition of Ayu post-larvae Plecoglossus altivelis. J. World Aquac. Soc. 34:85-91.

Cho, S. H., S. M. Lee, B. H. Park, S. C. Ji, C. Y. Choi, J. H. Lee, Y. C. Kim, J. H. Lee, and S. Y. Oh. 2007. Effect of daily feeding ratio on growth and body composition of subadult olive flounder, Paralichthys olivaceus, fed an extruded diet during the summer season. J. World Aquac. Soc. 38:68-73.

Cho, S. H. 2012. Effects of dietary nutrient on the biological index and serum chemistry of juvenile Olive flounder Paralichthys olivaceous achieving compensatory growth. Fish Aquat. Sci. 15:69-72.

Dwyer, K. S., J. A. Brown, C. Parrish, and S. P. Lall. 2002. Feeding frequency affects food consumption, feeding pattern and growth of juvenile yellowtail flounder (Limanda ferruginea). Aquaculture 213:279-292.

Folkvord, A. and H. Ottera. 1993. Effects of initial size 
distribution, day length, and feeding frequency on growth, survival and cannibalism in juvenile Atlantic cod (Gadus morhua). Aquaculture 114:243-260.

Gardeur, J. N., N. Mathis, A. Kobilinsky, and J. Brun-Bellut. 2007. Simultaneous effects of nutritional and environmental factors on growth and flesh quality of Perca fluviatilis using a fractional factorial design study. Aquaculture 273:50-63.

Hutson, A. M., L. A. Toya, and D. Tave. 2013. Effect of High Stocking Rates on Growth and Survival of the Endangered Rio Grande Silvery Minnow Hybognathus marus. Fish Aquat. Sci. 16:285-290.

Kayano, Y., S. Yao, S. Yamamoto, and H. Nakagawa. 1993. Effects of feeding frequency on the growth and body constituents of young red-spotted grouper, Epinephelus akaara. Aquaculture 110:271-278.

Kim, K. D., Y. J. Kang, K. W. Kim, and K. M. Kim. 2007. Effects of feeding rate on growth and body composition of juvenile flounder. J. World Aquac. Soc. 38:169-173.

Lee S. M., U. G. Hwang, and S. H. Cho. 2000. Effects of feeding frequency and dietary moisture content on growth, body composition and gastric evacuation of juvenile Korean rockfish (Sebastes schlegeli). Aquaculture 187:399-409.

Lee, S. M. and M. A. Pham. 2010. Effects of feeding frequency and feed type on the growth, feed utilization and body composition of juvenile olive flounder (Paralichthys olivaceus). Aquac. Res. 41:e166-e171.

Mizanur, R. M. and S. C. Bai. 2014. A review of the optimum feeding rates and feeding frequency in Korean rockfish (Sebastes schlegeli) reared at seven different water temperatures. Fish Aquat. Sci. 17:1-19.

Mizanur, R. M., G. Park, H. H. Yun, S. Lee, S. Choi, and S. C. Bai. 2014a. The effects of feeding rates in juvenile Korean rockfish (Sebastes schlegeli) reared at $17^{\circ} \mathrm{C}$ and $20^{\circ} \mathrm{C}$ water temperatures. Aquacult. Int. 22:1121-1130.

Mizanur, R. M., H. H. Yun, M. Moniruzzaman, F. Ferreira, K-W. Kim, and S. C. Bai. 2014b. Effects of feeding rate and water temperature on growth and body composition of Juvenile Korean Rockfish, Sebastes schlegeli (Hilgendorf 1880). Asian Australas. J. Anim. Sci. 27:690-699.

Moore, R. K., A. P. Scott, and P. M. Collins. 2000. Circulating C21 steroids in relation to reproductive condition of a viviparous marine teleost, Sebastes rastrelliger (grass rockfish). Gen. Comp. Endocrinol. 117:268-280.

NRC. 2011. Nutrient Requirements of Fish and Shrimp. National Academies Press, NY, USA.

Oh, S. Y., C. H. Noh, R. S. Kang, C. K. Kim, S. H. Cho, and J. Y. Jo. 2008. Compensatory growth and body composition of juvenile black rockfish Sebastes schlegeli following feed deprivation. Fish. Sci. 74:846-852.
Okorie, O. E., J. Y. Bae, K. W. Kim, M. H. Son, J. W. Kim, and S. C. Bai. 2013. Optimum feeding rates in juvenile olive flounder, Paralichthys olivaceus, at the optimum rearing temperature. Aquac. Nutr. 19:267-277.

Park, I. S., C. H. Kim, and J. W. Choi. 2012. Histological observations and regeneration of barbles in juveniles of the Chinese Longsnout catfish Leiocassis longirostris. Fish Aquat. Sci. 15:299-303.

Person-Le, R. J., V. Buchet, B. Vincent, D. H. Le, and L. Quemener. 2006. Effects of temperature on the growth of pollack (Pollachius pollachius) juveniles. Aquaculture 251:340-345

Qiao, G., S. I. Park, and D. H. Xu. 2012. Clinical, hematological and biochemical alterations in Olive flounder Paralichthys olivaceus following experimental infection by Vibrio scophthalmi. Fish Aquat. Sci. 15:233-239.

Schnaittacher, G., W. V. King, and D. L. Berlins. 2005. The effects of feeding frequency on growth of juvenile Atlantic halibut (Hippoglossus hippoglossus). Aquac. Res. 36:370-377.

Silva, C. R., L. C. Gomes, and F. R. Brandao. 2007. Effect of feeding rate and frequency on tambaqui (Colossoma macropomum) growth, production and feeding costs during the first growth phase in cages. Aquaculture 264:135-139.

Seo, J-Y. and S-M Lee. 2008. Effects of dietary macronutrient level and feeding frequency on growth and body composition of juvenile rockfish (Sebastes schlegeli). Aquacult. Int. 16:551560

Tucker, B. J., M. A. Booth, G. L. Allan, D. Booth, and D. S. Fielder. 2006. Effects of photoperiod and feeding frequency on performance of newly weaned Australian snapper, Pagrus auratus. Aquaculture 258:514-520.

Van Ham, E. H., M. H. G. Berntssen, A. K. Imsland, A. C. Parpoura, B. S. E. Wenderlaar, and S. O. Stefansson. 2003. The influence of temperature and ration on growth, feed conversion, body composition and nutrition retention of juvenile turbot (Scohthalmus maximus). Aquaculture 217:547-558.

Wang, N., X. Xu, and P. Kestemont. 2009. Effect of temperature and feeding frequency on growth performances, feed efficiency and body composition of pikeperch juveniles (Sander lucioperca). Aquaculture 289:70-73.

Xia, J. and X. Li. 2010. Effect of temperature on blood parameters of the salamander Batrachupems tibetanus (Schmidt, 1925) (Amphibia: Hynobiidae). Russian J. Ecol. 41:102-106.

Xie, F., Q. Ai, K. Mai, W. Xu, and H. Ma. 2011. The optimal feeding frequency of large yellow croaker (Pseudosciaena crocea, Richardson) larvae. Aquaculture 311:162-167. 